\title{
The Walls of the Extremely Halophilic Cocci: Gram-positive Bacteria Lacking Muramic Acid
}

\author{
By A. D. BROWN AND K. Y. CHO \\ School of Microbiology, University of New South Wales, \\ Kensington, N.S.W., and Department of Microbiology, \\ University of Sydney, Sydney, N.S.W., Australia
}

(Accepted for publication 27 April 1970)

The extremely halophilic cocci, Sarcina litoralis and $S$. morrhuae are sometimes described as either Gram-negative or Gram-variable (see, for example, Brown, 1964; Larsen, 1967) but, unlike the halobacteria, they are generally acknowledged to be resistant to lysis in dilute solution. If a smear is made from a suspension of the organisms in distilled water, they appear to be Gram-variable, but a smear prepared from a saline suspension stains characteristically Gram-positive (A. D. Brown, unpublished observation). Antill (1969) noted that lysozyme had no action on these organisms and could detect no muramic acid in $6 \mathrm{~N}$-acid hydrolysates of whole bacteria. The walls of two strains of halococci were therefore isolated and analysed. They contained no muramic acid and hence none of the peptidoglycan which is characteristic of other Gram-positive bacteria.

Cultures of Sarcina litoralis and S. morrhuae obtained from Dr J. H. B. Christian were maintained at 0 to $4^{\circ}$ on peptone agar ( $\mathrm{I} \% \mathrm{w} / \mathrm{v}$ Oxoid peptone) prepared in the salts solution of Sehgal \& Gibbons (1960). They were grown in the same peptone + salts solution supplemented with yeast extract $(0 . \mathrm{I} \% \mathrm{w} / \mathrm{v})$. Cultures were incubated with rotary agitation for 4 to 6 days at $40^{\circ}$. The bacteria were harvested by centrifugation at $0^{\circ}$ and washed three times with cold basal salts solution. The pellet was frozen and the organisms disrupted by shearing in a press similar in principle to the Hughes press. (Shaking with glass beads for $2 \mathrm{~h}$. in a Mickle tissue disintegrator caused negligible breakage.) The disrupted suspension was diluted up to tenfold with $\mathrm{MgCl}_{2}$ $(0.02 \mathrm{M})$ and incubated with deoxyribonuclease according to Brown, Shorey \& Turner (1965) in order to lower viscosity. The suspension was centrifuged for $30 \mathrm{~min}$. at $12,000 \mathrm{~g}$ and the supernatant fluid was discarded. The pellet was suspended in water, 2.5 or $5.0 \mathrm{M}-\mathrm{NaCl}$ and centrifuged alternately for $5 \mathrm{~min}$. at $300 \mathrm{~g}$ and for $30 \mathrm{~min}$. at $\mathrm{I} 2,000 \mathrm{~g}$ for 3 or 4 cycles. The walls were unusually dense and sedimented appreciably at $300 \mathrm{~g}$, even in $5.0 \mathrm{M}-\mathrm{NaCl}$. No special attempts were made to purify the walls. Microscopic examination showed them to contain from I to $10 \%$ (by number) whole organisms. Suspensions prepared in water were freeze-dried. Suspensions prepared in $\mathrm{NaCl}$ were dialysed against water ( 8 to Io changes of water, dilution ratio about $\mathrm{I} / 50$ for 4 days at $4^{\circ}$ ) and then freeze-dried. Carbohydrates were tentatively identified by paper chromatography of acid hydrolysates $\left(2 \mathrm{~N}-\mathrm{HCl}\right.$ for $2 \mathrm{~h}$. at $\left.100^{\circ}\right)$ in $n$-butanol/ pyridine/water ( $6: 4: 3$ by vol.) and detection with aniline phthalate and with silver nitrate. The presence of glucose and galactose was confirmed with their respective oxidases. Amino sugars were identified by paper chromatography of the same acid 
hydrolysates for 45 to $48 \mathrm{~h}$. in $n$-butanol/pyridine/acetic acid/water $(60: 40: 3: 30$ by vol.) and detection with ninhydrin. The absorption spectrum of the reaction product with $p$-dimethylaminobenzaldehyde (Rondle \& Morgan, I955) was examined for evidence of muramic acid. Acid hydrolysates (constant boiling $\mathrm{HCl}$ for $15 \mathrm{~h}$. at $100^{\circ}$ ) were examined for $\alpha, \epsilon$-diaminopimelic acid by paper chromatography in the solvent system of Rhuland, Work, Denman \& Hoare (1955) and for other amino acids by two-dimensional paper chromatography. Ash content was determined after combustion of walls in the presence of $\mathrm{HCl}$; the metal ion composition of the ash was determined by atomic absorption spectrophotometry. Elementary analyses for carbon, hydrogen and nitrogen were done by conventional combustion techniques. Total phosphorus was estimated as previously described (Brown, 1961). Amino acids were estimated with a Beckman model I $20 \mathrm{C}$ amino acid analyser after hydrolysis of the walls for $24 \mathrm{~h}$. at $100^{\circ}$ in constant boiling $\mathrm{HCl}$ under $\mathrm{N}_{2}$. Protein was estimated by the method of Lowry, Rosebrough, Farr \& Randall (I95I) after suspending the walls for I to I.5 h. in $1 \cdot 0 \mathrm{~N}-\mathrm{NaOH}$ at room temperature. Probable limits of nucleic acid concentration were deduced from phosphorus content and from the absorption spectrum of a solution obtained by hydrolysing the walls for $\mathrm{I} h$. at $100^{\circ}$ in a $\mathrm{I} \cdot \mathrm{ON}-\mathrm{HCl}$ and filtering the diluted hydrolysate through a membrane filter. The following estimations were made on acid hydrolysates $\left(2 \cdot 0 \mathrm{~N}-\mathrm{HCl}\right.$ for $2 \mathrm{~h}$. at $\left.100^{\circ}\right)$ : total hexose by the primary cysteine- $\mathrm{H}_{2} \mathrm{SO}_{4}$ reaction (Dische, 1955 ) with the assumption that the three hexoses were present in approximately equal proportions; 'reducing substances' (Park \& Johnson, 1949); amino sugar (Rondle \& Morgan, 1955). The bacteria were prepared for electron microscopy by the method of Cho, Doy \& Mercer (1967).

In section, the bacteria resemble non-halophilic species of Sarcina and have thick walls of a type generally characteristic of Gram-positive micro-organisms (P1. I). The wall preparations were faintly pigmented, presumably because of 'contaminating' whole organisms and residual membrane fragments. The freeze-dried preparations were softer, stickier and apparently more hygroscopic than is usual for walls of other Grampositive bacteria. They were easily redispersed in both acidic and alkaline solutions with little evidence of flocculation. Acid hydrolysates of walls from both species contained glucose, galactose and a third sugar, possibly mannose, in about equal proportions, as well as a compound tentatively identified as glucuronic acid. Glucosamine and galactosamine were present in about equal proportions, but no muramic acid was detected in hydrolysates of wall preparations (up to $4 \mathrm{mg}$.) nor of whole organisms ( 5 to ro mg.) which had been freed of salt by washing with cold trichloroacetic acid $(5 \% \mathrm{w} / \mathrm{v})$ followed by ether to remove the trichloroacetic acid. No diaminopimelic acid was detected but the common protein amino acids were present.

There were some minor quantitative differences between the two species (Table I) but they could not be attributed to differences in preparation. The high glycine content is noteworthy. If it is assumed that the glycine content of the protein(s) is slightly less than that of alanine, then the value of $3.5 \%$ shown in Table I can be divided into about $0.9 \%$ attributable to protein with the remaining $2.6 \%$ in some other form. The proportional amino acid composition of acid-hydrolysed walls of Sarcina morrhuae was remarkably similar to that of the membrane protein of Halobacterium halobium (see Marshall, Wicken \& Brown, 1969). The excess (asp+glu)-(arg + lys), was 16.5 moles/100 moles in the halococcal wall preparation compared with 19 in the membrane of $H$. halobium. This is, perhaps, added reason for assuming that the 
protein was associated largely with adhering membrane fragments. The ash content was unusually high but since it contained $89 \% \mathrm{NaCl}$ there is no reason to suppose that it reflected anything other than slow diffusion of salt out of the wall. Finally, it should be noted that the analyses listed in Table I account for only $70 \%$ of the total nitrogen.

Table I. Quantitative analyses of halococcal walls

\begin{tabular}{|c|c|c|c|c|c|c|c|c|c|c|c|}
\hline Organism & $\begin{array}{c}\text { Toial } \\
\mathrm{P} \\
(\%)\end{array}$ & $\begin{array}{c}\text { Total } \\
\text { hexose } \\
(\%)\end{array}$ & $\begin{array}{c}\text { Reducing } \\
\text { substances } \\
\text { (as glucose, } \\
\% \text { ) }\end{array}$ & $\begin{array}{c}\text { Amino } \\
\text { sugar (as } \\
\text { glucosamine } \\
\% \text { ) }\end{array}$ & $\begin{array}{c}\text { Protein } \\
(\%)\end{array}$ & $\begin{array}{c}\text { Nucleic } \\
\text { acid } \\
\text { (probable } \\
\text { limits } \% \text { ) }\end{array}$ & $\begin{array}{c}\text { Total } \\
\text { glycine* } \\
(\%)\end{array}$ & $\begin{array}{c}\text { Ash } \\
\text { (as } \\
\text { chloride } \\
\% \text { ) }\end{array}$ & $\begin{array}{l}\text { Total } \\
\text { C } \\
(\%)\end{array}$ & $\begin{array}{c}\text { Total } \\
\mathbf{H} \\
(\%)\end{array}$ & $\begin{array}{c}\text { Total } \\
N \\
(\%)\end{array}$ \\
\hline $\begin{array}{c}\text { Sarcina litoralis } \\
\text { Preparations }\end{array}$ & 0.12 & & & & & & & & & & \\
\hline S. morrhuae & 0.12 & 21 & 301030 & $5 \cdot 0$ to 5.4 & 6.7 to 8.4 & - & - & - & - & - & - \\
\hline $\begin{array}{l}\text { Preparation } 4 \\
\text { * See text. } \\
\dagger \text { Contained } 8 \\
\text { Preparations } \\
5 \mathrm{M}-\mathrm{NaCl} \text {. }\end{array}$ & $\begin{array}{l}\% \mathrm{Ni} \\
2, \text { an }\end{array}$ & $\begin{array}{l}\mathrm{aCl} \\
\mathrm{ad} 3 \mathrm{w}\end{array}$ & 201031 & $\begin{array}{c}7.5108 .0 \\
7.7\end{array}$ & $\begin{array}{l}4 \cdot 2 \\
8 \cdot 0\end{array}$ & $I \cdot 0$ to $I \cdot 3$ & $3 \cdot 5$ & $11.9 \dagger$ & $29 \cdot 38$ & $5 \cdot 70$ & $3 \cdot 72$ \\
\hline
\end{tabular}

The walls of the halococci are thus fundamentally different from those of other Gram-positive bacteria. The absence of muramic acid in the haloccoci as well as the halobacteria (Brown \& Shorey, I963) provides additional evidence that extreme halophils, in general, are incapable of synthesizing this compound.

We wish to thank Dr Ernest Challen of the Chemistry School and Mr Robert Whittaker of the Biochemistry School, University of New South Wales, for the elementary microanalyses and the amino acid analyses respectively.

\section{REFERENCES}

ANTILl, L. (1969). The Growth and Morphology of Halophilic Bacteria. B.Sc. (Hons.) Thesis, University of Sydney.

Brown, A. D. (1961). The peripheral structures of Gram-negative bacteria. I. Biochimica et Biophysica Acta 48, 352-361

Brown, A. D. (1964). Aspects of bacterial response to the ionic environment. Bacteriological Reviews 28, 296-329.

Brown, A. D. \& Shorey, C. D. (1963). The cell envelopes of two extremely halophilic bacteria. Journal of Cell Biology r8, 68 I-689.

Brown, A. D., Shorey, C. D. \& Turner, H. P. (1965). An alternative method of isolating the membrane of a halophilic bacterium. Journal of General Microbiology 4I, 225-23I.

Chо, K. Y., Doy, C. H. \& Mercer, E. H. (1967). Ultrastructure of the obligate halophilic bacterium Halobacterium halobium. Journal of Bacteriology 94, 196-201.

DisCHE, Z. (1955). New colour reagents for determination of sugars in polysaccharides. Methods of Biochemical Analysis 2, 313-358.

LARSEN, H. (1967). Biochemical aspects of extreme halophilism. Advances in Microbial Physiology I, 97-132.

Lowry, O. H., Rosebrough, N. J., Farr, A. L. \& Randall, R. J. (I95I). Protein measurement with the Folin phenol reagent. Journal of Biological Chemistry 193, 265-275.

Marshall, C. L., Wicken, A. J. \& Brown, A. D. (I969). The outer layer of the cell envelope of Halobacterium halobium. Canadian Journal of Biochemistry 47, 7I-74.

PARK, J. T. \& Johnson, M. J. (I949). A submicrodetermination of glucose. Journal of Biological Chemistry 181, I49-15I. 
Rhuland, L. E., Work, E., Denman, R. F. \& Hoare, D. S. (1955). The behaviour of the isomers of $\alpha, \epsilon$-diaminopimelic acid on paper chromatograms. Journal of the American Chemical Society 77, 4844-4846.

Rondle, C. J. M. \& Morgan, W. T. J. (1955). The determination of glucosamine and galactosamine. Biochemical Journal 6r, 586-589.

SeHgal, S. N. \& GibBons, N. E. (1960). Effect of some metal ions on the growth of Halobacterium cutirubrum. Canadian Journal of Microbiology 6, I65-169.

\section{EXPLANATION OF PLATE}

Electron micrograph of sectioned Sarcina morrhuae. The average wall thickness in this illustration is about $900 \AA$ but thicker walls are often encountered. $\times 44,250$. 
Journal of General Microbiology, Vol. 62, No. 2

Plate I

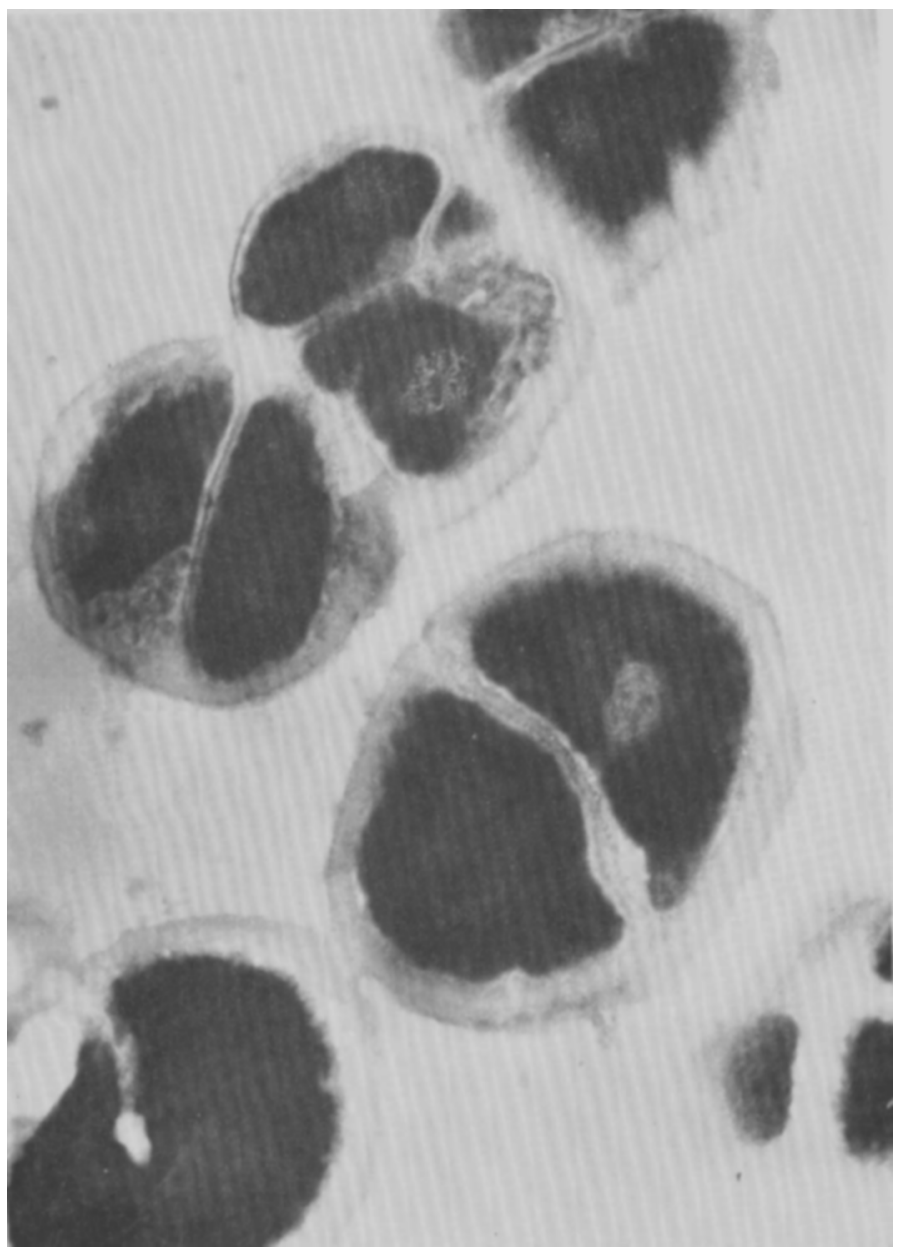

A. D. BROWN AND K. Y. CHO

(Facing p. 270) 